\title{
Long-term trends in food habits of a relict brown bear population in northern Spain: the influence of climate and local factors
}

\author{
C. RODRÍGUEZ ${ }^{1,2 *}$, J. NAVES $^{1,2}$, A. FERNÁNDEZ-GIL ${ }^{1,2}$, J.R. OBESO ${ }^{1}$ AND M. DELIBES ${ }^{2}$ \\ ${ }^{l}$ Departamento de Biología de Organismos y Sistemas, Unidad de Ecología, Universidad de Oviedo, Oviedo, Spain, and ${ }^{2}$ Department of Applied \\ Biology, Estación Biológica de Doñana, CSIC, Avda María Luisa s/n Sevilla, Spain \\ Date submitted: 15 March 2006 Date accepted: 31 October 2006 First published online: 14 March 2007
}

\section{SUMMARY}

Relict endangered populations may be especially vulnerable to the effects of climate change. A data series for the period 1974-2003 was used to examine shifts in brown bear Ursus arctos food habits in its south-westernmost European population. This focused on the hyperphagic season, when bears gain the fat that is essential for winter dormancy and reproduction. General climatic indicators were predictors of diet trends. Other variables potentially able to modify brown bear food habits at the local scale were accounted for by considering two areas where local conditions changed in different ways during the study period. General climatic indicators such as temperature and the winter North Atlantic Oscillation index were good predictors of some diet trends, although local factors seemed to modulate the potential response of food habits to recent climate change. Boreal and temperate food items decreasingly contributed to brown bear diet, replaced by increasing contributions of southern foods, which suggested that warmer temperatures might determine the occurrence of some food items in the diet of Cantabrian brown bears through effects on plant distribution and phenology. At the local scale, high cattle density in one of the study areas limited food sources available for brown bears. Important food sources for brown bears, such as heath-like Vaccinium formations and old-growth oak forest in the Cantabrian Mountains, require increased levels of protection.

Keymords: brown bear, Cantabrian Mountains, global warming, interspecific competition, nutritional balance, Quercus petraea, Ursus arctos, Vaccinium myrtillus

\section{INTRODUCTION}

Global environmental conditions are changing at an unprecedented rate (IPCC [Intergovernmental Panel on Climate Change] 2001), among other impacts causing modifications in the distribution ranges of species, both latitudinal (Parmesan

\footnotetext{
* Correspondence: Dr Carlos Rodríguez, University of Jena, Institute of Ecology, Dornburger Strasse 159, D-07743 Jena, Germany Tel: +493641 949451 Fax: +493641 949402 e-mail: carlos. rodriguez@uni-jena.de
}

et al. 1999) and altitudinal (Peñuelas \& Boada 2003), changes in phenology (Peñuelas \& Filella 2001), subsequent mistimed ecological processes (Visser et al. 1998) and concomitant losses in biodiversity (Pimm et al. 1995; Thomas et al. 2004). The effects of climate change are especially dramatic for relict, endangered populations, because of their comparatively fewer opportunities to escape from climate change (Thomas et al. 2004) or the lower genetic flow that would allow them to cope with this change (Jump \& Peñuelas 2005). The effects of recent climate change (local extinctions, range displacements) are the result of a cumulative set of less apparent responses of ecological processes (such as reduced fecundity; Hampe 2005) sensitive to this change. There is a strong bias in studies investigating the responses of populations to recent climate change towards expanding edges of population ranges, despite the key role played by populations at the contracting edge in the maintenance of biodiversity (Hampe \& Petit 2005). The performance of contracting-edge populations under modern climate change is a topic that particularly merits the development of research and conservation measures (Hampe \& Petit 2005).

We focused on the brown bear Ursus arctos in the Cantabrian Mountains of north-western Spain, the current south-westernmost boundary of the species range, where it still survives as a small population (around 100 individuals; Servheen et al. 1999) relegated to most inaccessible slopes and constrained by both natural and human factors (Wiegand et al. 1998; Naves et al. 2003). This mountain range contains the largest portion of the remnant Atlantic deciduous forests on the Iberian peninsula, also representing the southernmost boundary of this system in western Europe (Polunin \& Walters 1985), and characterized by highly fragmented forest patches of relatively low cover (García et al. 2005).

We investigated whether there were temporal trends in consumption of the brown bear's primary foods in the Cantabrian range during 1974-2003, a period of acute recent climate warming (Peñuelas \& Filella 2001). Our overall aim was to identify whether recent climate changes could explain any of these trends. Because of the strong seasonal variation in the bear's food habits (Mattson et al. 1991; Craighead et al. 1995; Naves et al. 2006), we focused on the hyperphagic season, when bears strongly depend on feeding conditions for fat deposition prior to winter dormancy (see Lefranc et al. 1987; Mattson et al. 1991; Craighead et al. 1995). In the Cantabrian population, hyperphagia begins in early July after courtship (Fernández-Gil et al. 2006), and lasts until mid-November when pregnant females enter the den, relying 
on their fat reserves not only for their own survival, but also for gestation development, birth of cubs and early lactation (Craighead \& Mitchell 1982; LeFranc et al. 1987).

Vegetation is sensitive to recent climate warming, especially at boundary areas, where forest patches of relict temperate species are progressively isolated, suffering declines in recruitment and fruit production (Peñuelas \& Boada 2003; Hampe 2005). Bears are highly herbivorous (up to $89 \%$ of total diet volume; Clevenger et al. 1992; Naves et al. 2006), and need large amounts of food to fulfil their energy requirements (Welch et al. 1997). Bears are also able to respond quickly to changes in food availability (Mattson et al. 1991; Craighead et al. 1995; Naves et al. 2006); we anticipated long-term changes in diet composition because climate change affects each plant species in the diet of brown bears differently, with relict boreal and temperate species expected to shift towards higher altitudes to be replaced by Mediterranean (southern) species (Peñuelas \& Boada 2003).

Many factors other than recent climate warming can also significantly influence food availability or accessibility over given time periods, and should be considered as potential predictors of diet trends. Bears may shift their diet because of interspecific competition, and thus changes in the local abundances of competitors (wild ungulates and free-ranging livestock) could influence bears' food habits. Since shifts in the patterns of habitat use by bears could influence diet composition as well, we also considered drivers of these changes, such as tourism pressure or forestry actions. To account for these potential influences, we investigated brown bear food habits in two different areas within the Cantabrian Mountains where both the relative importance of these local factors and their temporal trends differ, and we expected their impact on diet composition to differ.

If factors impacting the entire study range, such as climate warming, play the major role in brown bear food habits, we predicted that there would be (1) a decreasing contribution of those food items negatively influenced by increasing temperatures, and (2) similar diet trends for the two areas considered in the Cantabrian Mountains. Conversely, if local factors, such as competitors or tourism activities, play the major role on brown bear food habits, the two areas considered here should differ in their diet trends. In the case of competitors, since they only share a part of their diet with the brown bear, the higher the population of competitors, the lower the expected contribution of shared food items to the bear's diet. If both local and global factors govern changes in brown bear food habits, the interaction between them, whether synergistic or antagonistic will determine the patterns of change in the relative contribution of each food item to diet.

We aimed to consider how changes in brown bears' food habits should influence the aims and practices of the conservation efforts oriented to avoid the extinction of this relict population, and how potential changes in food availability may influence other species of special conservation concern in the Cantabrian Mountains.

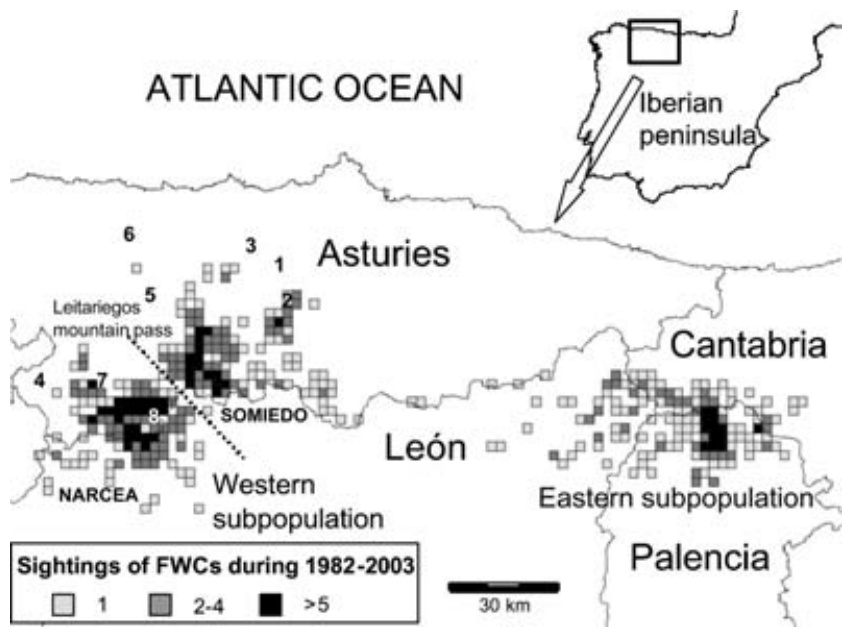

Figure 1 Distribution range of brown bears in the Cantabrian Mountains. We delineated the study areas (Somiedo and Narcea) by habitat features and the sightings of female with cubs (FWCs) based on a $2.5 \times 2.5 \mathrm{~km}^{2}$ grid. The ID numbers indicate the location of weather stations where meteorological data were obtained (see Table 2).

\section{METHODS}

\section{Study area}

The Cantabrian Mountains of north-western Spain run eastwest along the Atlantic coast, with a maximum altitude of $2648 \mathrm{~m}$ (Fig. 1). The chain's proximity to the ocean and the geographic orientation result in high rainfall on north-facing slopes and a rain shadow on southern slopes (average annual rainfall of 900-1900 mm versus 400-700 mm). Woodland cover is varied, with beech Fagus sylvatica, oak (predominantly Quercus petraea, but also Q. pyrenaica and Q. ilex) and chestnut trees Castanea sativa. Above 1700$2300 \mathrm{~m}$, climatic conditions prevent forest growth, and sub-alpine shrubs (such as Calluna vulgaris, Erica spp. and Vaccinium spp.) dominate (see Naves et al. 2006 for more details). The Cantabrian brown bear population has eastern and western subpopulations (Wiegand et al. 1998; Naves et al. 2003). We focused our work on the latter, because sample size in the former was inadequate for this study. We subdivided the western subpopulation into western (hereafter Narcea) and central (hereafter Somiedo) core areas because the Leitariegos Mountain Pass (Asturies/León Provinces) acts as a natural barrier, with roads, ski runs, a surface mine and a concentration of villages inhibiting bear movement between the two areas (Fig. 1). West of the Leitariegos Mountain Pass, limestone almost disappears and forest cover is denser than east of the Pass (45\% in Narcea versus 35\% in Somiedo) as is the percentage of oak-forest cover $(13 \%$ in Narcea versus $6 \%$ in Somiedo). In Somiedo, both livestock farming (i.e. potential competition) and tourism are important economic activities (Naves et al. 2001), while in Narcea, mining is the main local industry. No new highways, ski resorts, mines, major 
reforestations or timber harvestings have occurred during the study period.

\section{Faeces collection and analyses}

We collected 934 brown bear faeces in the whole Cantabrian range between 1974 and 2003, with 836 from the two core areas under study. All of them were from the bears' hyperphagic period (July-November, inclusive). We gathered most of the faeces (90\%) in the periods 1980-1987 and 1994-2002, during systematic surveys for the study and monitoring of the population. Faeces were stored frozen before they were analysed over a tray identifying all diet items to the finest taxonomic resolution possible. We visually estimated the percentage volume of each food item in the scat (details in Naves et al. 2006).

\section{Climate indicators}

We used as climate indicators the winter North Atlantic Oscillation (NAO) index, recently extended as a proxy of annual weather conditions in Europe (Ottersen et al. 2001; Rodríguez \& Bustamante 2003). This index is associated with a north-south oriented bipolar structure in the pressure over the Atlantic Ocean that affects the transport and convergence of atmospheric moisture in western European areas, with positive NAO values related to a decrease in moisture conditions, and negative values associated with more humid conditions (Hurrell \& van Loon 1997), especially during winter (Vicente-Serrano \& Heredia-Laclaustra 2004). We also considered the mean temperature during two periods influencing vegetation growth, namely January-August and April-August (Koenig \& Knops 2000). Since vegetation can respond to weather conditions with a certain delay, especially fruit production (Koenig \& Knops 2000), we also considered values from the previous year of both winter NAO index and mean annual temperatures. We gathered temperature information from the Zardain weather station because it is located at a similar distance from the two study areas (Fig. 1) and it has the same number of year-data for all temperature variables (Table 2).

\section{Temporal trends in local factors}

Wild and domestic ungulates consume resources such as grasses, forbs, fleshy and dry fruits, all of which are important for bears. We gathered information about ungulate densities, and their temporal trends across the study period. For domestic ungulates (goats, sheep, cattle and horses), we used data from the Department of Agriculture of the Asturies government (Obeso \& Bañuelos 2003). Game censuses (such as Consejería de Medio Ambiente del Principado de Asturies 2000) conducted by Asturies government-employed rangers provided densities of wild ungulates (Cantabrian chamois Rupicapra pyrenaica, red deer Cervus elaphus, roe deer Capreolus capreolus and wild boar Sus scrofa). Since this information was available on a county basis, we considered only ungulate densities in Degaña (within the Narcea area) and Somiedo, which were within the brown bear's range. To make the competition pressure played by different-sized ungulates more comparable, we transformed individual densities into biomass densities using available mean body mass values (Llaneza 1996; Jedrzejewski et al. 2002).

In Somiedo, a Natural Park created in 1988 led to increased numbers of visitors (six-fold growth between 1990 and 1998; Naves et al. 2001). Although we have no data on the annual number of visitors to Narcea, a Natural Park was created there only months before our study concluded (December 2002), and the low development of tourism services in the area suggests a lower tourism pressure than in Somiedo.

\section{Statistical analyses}

We ran generalized linear models (GLMs; McCullagh \& Nelder 1983) to investigate temporal trends in the most important food items (above 3\% of total volume). As response variable, we considered the quotient between the absolute frequency of yearly occurrence of each item (the number of faeces where the item was present in a substantive portion, i.e. $>9 \%$ of scat volume) and the number of faeces collected each year (thus allowing for sample size correction). As effect variables, we considered the year (as continuous variable), the winter NAO index values and the temperature values during the study period. Apart from cattle, only data on wild boar density in Somiedo were sufficient (see Results) to be used as an explanatory variable of the annual contribution of those food items consumed by both competitors and brown bear (graminoids and forbs for cattle, and acorns for wild boars; Table 1). Because $V$. myrtillus occurs from sea level to $>2000 \mathrm{~m}$ altitude (Fernández-Calvo \& Obeso 2004), the buffering effect of altitude on temperature could be masking the impact of temperature on this species and on its fruit consumers ( $V$. myrtillus at lower altitudes are expected to be more sensitive to climate warming than at higher altitudes). At lower altitudes, Vaccinium fruits also ripen earlier than at higher altitudes, and thus, we built separate models for their occurrence in the brown bear's diet in July-August (early),

Table 1 Diet overlap between the brown bear and competing ungulates during the hyperphagia season according to the Kulzynski similarity index (KSI) calculated by Anduix (2001) based on a bibliometric study. Higher values of the index indicate higher diet overlaps.

\begin{tabular}{lll}
\hline \hline Competitor & Summer & Fall \\
\hline Sheep & 0.17 & - \\
Goats & 0.28 & 0.43 \\
Cattle and horses & 0.38 & 0.43 \\
Wild boar & 0.58 & 0.64 \\
Chamoise & 0.5 & 0.14 \\
Red deer & 0.32 & 0.34 \\
Roe deer & 0.55 & 0.62 \\
\hline \hline
\end{tabular}


Table 2 Temporal trends in mean temperature from different weather stations in the Cantabrian brown bear range (slope and significance of the correlation between year and temperature: $\mathrm{ns}=$ not significant; $\left.{ }^{*} p<0.05 ;{ }^{* *} p<0.01 ;{ }^{* * *} p<0.001\right)$. The ID number used in Figure 1 identifies each weather station, and its altitude and working period are given. Because weather data were incomplete, the number of data years available for each of the temperature variables (which included different months) varied; this has a greater influence on the annual temperature than the temperature between April and August.

\begin{tabular}{llcllccc}
\hline \hline ID & Name & Altitude $(\mathrm{m})$ & Period & $\begin{array}{l}\text { Number of } \\
\text { years of data }\end{array}$ & $\begin{array}{c}\text { Annual } \\
\text { temperature }\end{array}$ & $\begin{array}{l}\text { Temperature } \\
\text { fan-Aug }\end{array}$ & $\begin{array}{c}\text { Temperature } \\
\text { Apr-Aug }\end{array}$ \\
\hline 1 & Grado & 60 & $1943-2004$ & $54-57$ & $0.4^{* * *}$ & $0.4^{* * *}$ & $0.3^{* * *}$ \\
2 & Proaza & 195 & $1971-2001$ & $25-30$ & $0.2 \mathrm{~ns}$ & $0.2^{* * *}$ & $0.1 \mathrm{~ns}$ \\
3 & Fenigonte & 260 & $1983-2003$ & $15-21$ & $0.7^{* *}$ & $1^{* * *}$ & $0.7^{* *}$ \\
4 & San Antolin & 309 & $1969-2003$ & $20-28$ & $0.3^{*}$ & $-0.4^{* * *}$ & $-0.4^{*}$ \\
5 & Arganza & 320 & $1970-2003$ & $29-32$ & $0.4^{* * *}$ & $0.5^{* * *}$ & $-0.3 \mathrm{~ns}$ \\
6 & Zardaín & 410 & $1968-2004$ & 36 & $0.3 \mathrm{~ns}$ & $0.4^{* * *}$ & $0.3 \mathrm{~ns}$ \\
7 & Moal & 610 & $1974-2003$ & $22-28$ & $0.6^{*}$ & $0.9^{* * *}$ \\
8 & Coto Cortés & 1350 & $1977-1998$ & $16-22$ & $0.9^{*}$ \\
\hline \hline
\end{tabular}

and September-October (late). We built GLM models with SAS V.9. We used a binomial function for errors and a logit link. We corrected data for over-dispersion when necessary. Since we expected curvilinear trends in the frequency of occurrence of each diet item in our long time series, we explored non-linear relationships for no significant linear models by using generalized additive models (GAMs), a generalization of GLM models that allows for the use of scatter plot smoothers to model non-linear relationships between response and explanatory variables. We fitted cubic smoothing splines with three degrees of freedom (Hastie \& Tibshirani $1990)$ to the variable year with the GAM procedure of Splus.

\section{RESULTS}

\section{Temporal trends of global and local variables}

The selected temperature variables increased over time in seven of the eight weather stations (Table 2).

Cattle were the main domestic ungulate in both areas, but their density was much higher in Somiedo than in Narcea (Fig. 2). Cattle density increased over time in Somiedo (slope coefficient of the linear model $=0.02 ; F=21.3 ; p=0.002)$, but decreased in Narcea (slope $=-0.04 ; F=24.6 ; p=0.002$ ). Among wild ungulates, the red deer was most important in Somiedo, but was almost absent in Narcea. Wild boars were abundant in both areas. They increased in Somiedo (slope $=0.07 ; F=78.4 ; p<0.001$ ) but not in Narcea (see Fig. 2). In Narcea, roe deer constituted the main wild ungulate, the only case of an ungulate species showing higher densities in Narcea than in Somiedo (Fig. 2). Potential competitors were thus much more abundant in Somiedo, where their densities increased, than in Narcea, where their densities decreased.

\section{Brown bear diet trends, and explanatory ability of both global and local factors}

Berries, fleshy fruits and dry fruits constituted the bulk of the Cantabrian bear's diet during the hyperphagic season.
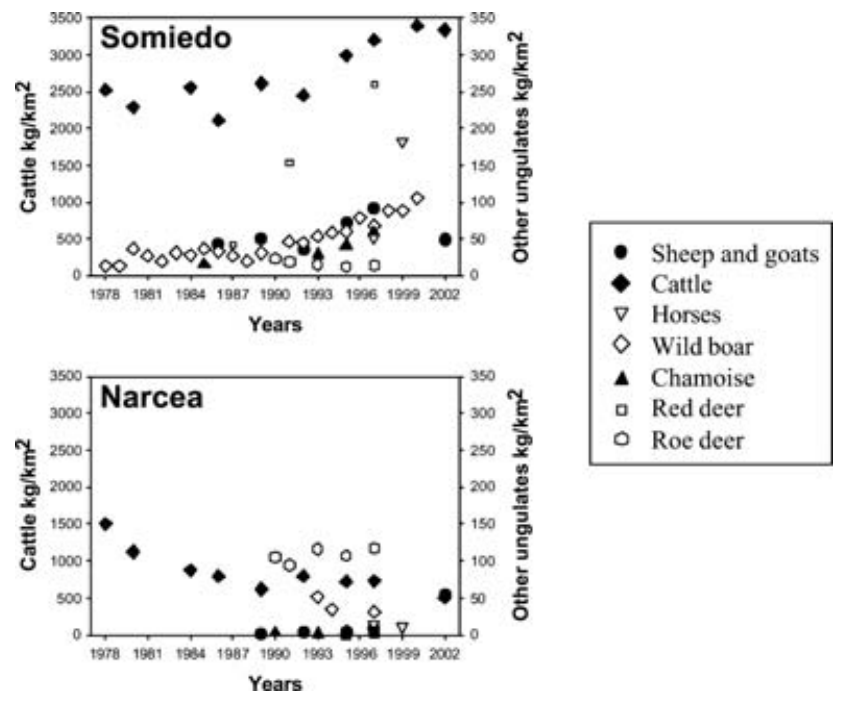

Figure 2 Ungulate densities across the study period in the two study areas, $y$-axes on the left of each plot corresponding to cattle density and $y$-axes on the right corresponding to densities of the remaining ungulates (both wild and domestic).

The annual contribution to diet of some food items showed temporal changes, consumption of Prunus fruits increasing in both areas (Table 3 ). The contribution of vertebrates to brown bear diet increased in Narcea, where the relative importance of acorns (Quercus spp.) diminished. In Somiedo, bears increased their consumption of blackberries (Rubus spp.), but consumption of bilberries (Vaccinium spp.) and graminoids declined. Early bilberries showed negative trends in both study areas (Table 4), while late bilberries showed temporal trends in Somiedo (negative) different from those in Narcea (positive). Although we found no linear temporal trends in diet either for Quercus or for Castanea in Somiedo, GAM analyses showed a U-shaped trend, with a minimum around 1987 in the consumption of Castanea, and a peak of Quercus consumption around 1994, patterns described by third degree splines (Fig. 3). 
Table 3 Results of GLM models of relationships between the occurrence of major food items during hyperphagia in the two study areas $(n=836)$ and the year (continuous variable). The relative importance of each food item is indicated by the $\%$ of diet volume. ns $=$ not significant; ${ }^{*} p<0.05$; ${ }^{* *} p<0.01 ;{ }^{* * *} p<0.001$. For significant models, we provide parameter estimates.

\begin{tabular}{|c|c|c|c|c|c|c|}
\hline \multirow[t]{2}{*}{ Item } & \multicolumn{3}{|c|}{ Somiedo } & \multicolumn{3}{|c|}{ Narcea } \\
\hline & $\begin{array}{l}\% \text { of diet } \\
\text { volume }\end{array}$ & $\begin{array}{l}\text { Parameter } \\
\text { estimate }\end{array}$ & Significance & $\begin{array}{l}\% \text { of diet } \\
\text { volume }\end{array}$ & $\begin{array}{l}\text { Parameter } \\
\text { estimate }\end{array}$ & Significance \\
\hline Malus & 13 & ns & ns & $<3$ & & \\
\hline Quercus & 12 & ns & ns & 23 & -0.07 & $* *$ \\
\hline Rhamnus & 10 & ns & ns & $<3$ & & \\
\hline Castanea & 10 & ns & ns & $<3$ & & \\
\hline Corylus & 9 & ns & ns & 8 & ns & ns \\
\hline Graminoids & 7 & -0.07 & $* *$ & 4 & ns & ns \\
\hline Vertebrates & 7 & ns & ns & 7 & +0.07 & $* *$ \\
\hline Vaccinium & 6 & -0.13 & $* *$ & 25 & ns & $\mathrm{ns}$ \\
\hline Prunus & 6 & +0.1 & $*$ & 10 & +0.2 & $* * *$ \\
\hline Forbs & 6 & ns & ns & 6 & ns & ns \\
\hline Insects & 4 & ns & ns & 5 & ns & ns \\
\hline Rubus & 4 & +0.11 & $*$ & $<3$ & & \\
\hline Sorbus & 3 & $\mathrm{~ns}$ & ns & $<3$ & & \\
\hline
\end{tabular}

Table 4 Results of GLM models of early (July-August) and late (September-October) consumption of Vaccinium fruits. Interaction between area and year was negligible in the first model $\left(\chi^{2}=0.23 ; p=0.63\right)$. The scale parameter was estimated by the square root of deviance/df.

\begin{tabular}{|c|c|c|c|c|c|c|c|}
\hline $\begin{array}{l}\text { Response } \\
\text { variable }\end{array}$ & $\begin{array}{l}\text { Explanatory } \\
\text { variables }\end{array}$ & & $\begin{array}{l}\text { Parameter } \\
\text { estimate }\end{array}$ & $S E$ & $\chi^{2}$ & $p$ & $\begin{array}{l}\% \text { of explained } \\
\text { deviance }\end{array}$ \\
\hline \multirow[t]{4}{*}{ Early } & & Intercept & 151.88 & 66.9 & & & \\
\hline & Area & Somiedo & Aliased & Aliased & 14.6 & 0.004 & 34 \\
\hline & & Narcea & 1.44 & 0.52 & & & \\
\hline & Year & & -0.08 & 0.03 & 5.63 & 0.02 & \\
\hline Late in & & Intercept & 312.6 & 123 & & & \\
\hline Somiedo & Year & & -0.16 & 0.06 & 7.9 & 0.005 & 38 \\
\hline Late in & & Intercept & 142.1 & 47.7 & & & \\
\hline Narcea & Year & & 0.07 & 0.02 & 10.3 & 0.001 & 42 \\
\hline
\end{tabular}

Figure 3 Temporal trends of Castanea and Quercus fruits in Somiedo. Third degree splines were fitted to variable year. Broken lines indicate the $\mathrm{SE}$ of the mean. The rugplot on the $\mathrm{x}$-axes indicates the density of data points.

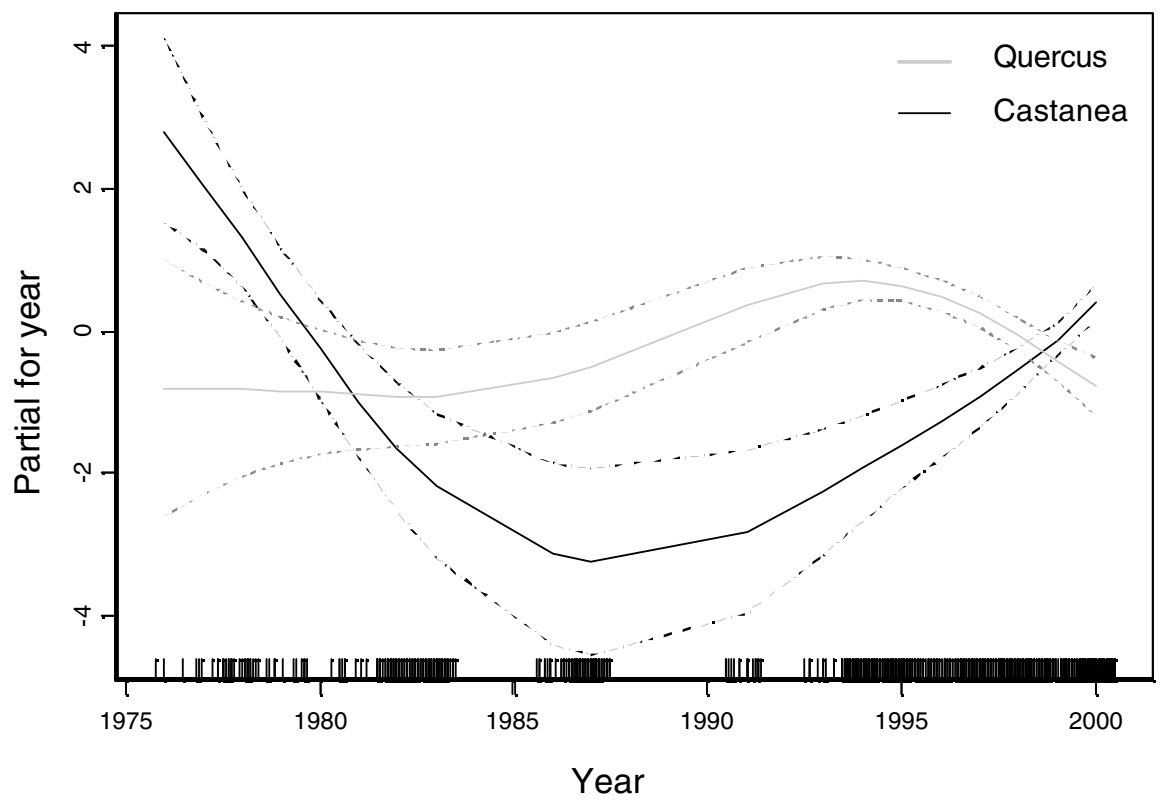

Both temperature values and, less so, the winter NAO index helped explain the annual consumption of many food items in the whole Cantabrian range (Table 5). We found a positive association between temperature and consumption of Prunus fruits throughout the entire Cantabrian range, which was concomitant with the increasing temporal trend found for this item in the two study areas. Conversely, trends in the consumption of other food, though showing patterns according to weather models (decreasing consumption of acorns and graminoids) were only detected in one of the study areas. We found no significant relationship between the density of competitors (see Fig. 2) and the contribution 
Table 5 The sign (in parentheses) and significance of relationships between annual contribution of food items to brown bear diet (\% total volume) throughout the entire Cantabrian range $(n=934$ faeces) ns $=$ not significant; $\ddagger p<0.1{ }^{*} p<0.05 ;{ }^{* *} p<0.01$; $* * * p<0.001$.

\begin{tabular}{lllllll}
\hline \hline Item & $\begin{array}{l}\text { \% of diet } \\
\text { volume }\end{array}$ & $\begin{array}{l}\text { Previous year } \\
\text { average } \\
\text { temperature }\end{array}$ & $\begin{array}{l}\text { Temperature } \\
\text { fan-Aug }\end{array}$ & $\begin{array}{l}\text { Temperature } \\
\text { Koenig }\end{array}$ & $\begin{array}{l}\text { Winter } \\
\text { NAO }\end{array}$ & $\begin{array}{l}\text { Previous year } \\
\text { pinter NAO }\end{array}$ \\
\hline Ouercus & 16 & $(-)^{*}$ & $\mathrm{~ns}$ & $\mathrm{~ns}$ & $\mathrm{~ns}$ & $(-) \ddagger$ \\
Vaccinium & 11 & $\mathrm{~ns}$ & $\mathrm{~ns}$ & $\mathrm{~ns}$ & $\mathrm{~ns}$ & $\mathrm{~ns}$ \\
Malus & 7 & $(+) \ddagger$ & $\mathrm{ns}$ & $\mathrm{ns}$ & $\mathrm{ns}$ & $\mathrm{ns}$ \\
Rhamnus & 7 & $\mathrm{~ns}$ & $\mathrm{~ns}$ & $\mathrm{~ns}$ & $\mathrm{~ns}$ & $\mathrm{~ns}$ \\
Graminoids & 7 & $(-) \ddagger$ & $(-)^{*}$ & $(-)^{* *}$ & $(-)^{* *}$ & $\mathrm{~ns}$ \\
Castanea & 7 & $\mathrm{~ns}$ & $\mathrm{~ns}$ & $\mathrm{~ns}$ & $(+) \ddagger$ & $\mathrm{ns}$ \\
Vertebrates & 7 & $(+)^{* *}$ & $(+)^{* *}$ & $(+)^{*}$ & $\mathrm{~ns}$ & $\mathrm{~ns}$ \\
Prunus & 7 & $(+)^{* *}$ & $(+)^{* *}$ & $(+)^{* *}$ & $\mathrm{~ns}$ & $\mathrm{~ns}$ \\
Forbs & 7 & $(-) \ddagger$ & $(-)^{*}$ & $(-)^{* *}$ & $\mathrm{~ns}$ & $\mathrm{~ns}$ \\
Corylus & 6 & $\mathrm{~ns}$ & $(+)^{* * *}$ & $(+)^{* *}$ & $\mathrm{~ns}$ & $\mathrm{~ns}$ \\
Insects & 4 & $\mathrm{~ns}$ & $(+)^{* *}$ & $\mathrm{~ns}$ & $\mathrm{~ns}$ & $\mathrm{~ns}$ \\
Rubus & 3 & $\mathrm{~ns}$ & $\mathrm{~ns}$ & $\mathrm{~ns}$ & $\mathrm{~ns}$ & $(-)^{* *}$ \\
Sorbus & 3 & $\mathrm{~ns}$ & $\mathrm{~ns}$ & $\mathrm{~ns}$ & $\mathrm{~ns}$ & $(+) \ddagger$ \\
\hline \hline
\end{tabular}

to brown bear diet of those food items that competitors also consume.

\section{DISCUSSION}

Several directional changes in brown bear food habits occurred in the Cantabrian range during the period 1974-2003, and our results suggest that both global and local factors may be partly responsible. Nonetheless, several shortcomings inherent to our study need to be recognized. Although brown bears are sensitive to changes in food availability because of their high energy requirements and essentially frugivorous diet during hyperphagia (Welch et al. 1997), we have no direct measurements regarding food availability or plant phenology, and thus our recommendations concerning these topics should be corroborated by field investigations. Climate change or local factors may determine trends in some food items, but the relative contribution to diet of others may secondarily increase or decrease simply because of these trends, and subsequent compensations of nutritional balance. For instance, if climate change produces declining availability of an optimal alpine fruit (such as Vaccinium), this decline could force bears to forage at lower altitudes where they simply cannot feed on other alpine foods (such as graminoids). Similar to other studies dealing with endangered populations, our results are based on a limited sample size, a limited time interval and only two 'replicate' areas in which the potential effect of recent climate change on brown bear food habits was studied.

We found a trend toward increased local temperatures over the study period. This is in accordance with increasing trends found in Western Europe for both temperature and values of the winter NAO index (Hurrell \& Van Loon 1997; Peñuelas \& Filella 2001; Osborn \& Briffa 2006).

Effects of recent climate change on vegetation have been reported in other areas of Northern Spain, where several plant species have shown marked changes in the phenology of leaf unfolding, flowering, fruiting or leaf fall (Peñuelas et al. 2002). Our results suggest that warming (see Table 2) may determine changes in food habits of Cantabrian brown bears through its effect on plant distribution and phenology. Peñuelas $e t$ al. (2002) demonstrated that some Prunus spp. are among the most sensitive to increasing temperatures, showing advances in fruiting of up to 25 days. Prunus fruits are some of the earliest to ripen (Eriksson \& Ehrlén 1991), so if an advance in fruiting has occurred in the Cantabrian range, bears may select these fruits to enrich the late spring-early summer diet mainly based on forbs and graminoids (Clevenger et al. 1992; Naves et al. 2006). Increasing temperatures have also encouraged the spread of Prunus species to previously unoccupied areas in central Europe (Sukkop \& Wurzel 2003). Thus, the earlier and/or higher availability of Prunus fruits caused by recent climate warming constitutes a plausible explanation for the positive relationship between temperature and contribution to diet of Prunus, as well as for the increasing consumption of this item by bears in two areas with different local anthropogenic constraints (Table 3).

In addition, several studies have documented the harmful effects of temperature warming on different features of Vaccinium myrtillus fitness (Ögren 1996; Taulavuori et al. 1998; Tolvanen \& Taulavuori 1998; Beerling 1999). In the Cantabrian range, this effect was only apparent for early Vaccinium fruits at lower altitudes, which showed a negative trend over time in Somiedo and Narcea (Table 4). However, climate warming seems to have less influence on late consumption of Vaccinium fruits (September-October), which seems governed by local factors, as indicated by the existence of opposite temporal diet trends in the two study areas (Table 4) and the subsequent lack of significant climate models for the entire Cantabrian range (Table 5).

The climate-related hypothesis was speculative for the remaining food items showing temporal trends, primarily because these trends differed between the two study areas, but also because there are few previous studies supporting reasonable hypotheses on the response of these species to recent climate warming. For instance, the consumption of acorns showed different temporal trends in the two study areas. They clearly declined in Narcea, but only during recent years in Somiedo (Fig. 3). Fruit production of Quercus species 
is particularly complex (Herrera et al. 1998), and consumption trends of acorns are not comparable between the two study areas because two deciduous oak species (Quercus petraea and $Q$. pyrenaica) occurred in Narcea, while an additional evergreen Mediterranean oak species $(Q$. ilex $)$ occurred in Somiedo. Peñuelas $e t$ al. (2002) documented an advance of Q. ilex fruiting in NE Spain, and this additional species and the consequences of its earlier fruiting could explain the more complex acorn pattern found in Somiedo (see Fig. 3). Bears in this area also consumed Castanea fruits at this time, following a temporal trend that might be complementary to acorn consumption. Thus, different responses of these synchronous items to climate may also be behind these diet trends, although further studies on factors influencing fruit production in both Quercus and Castanea probably need a longer time series.

Recent climate warming thus seems to explain part of the documented changes in brown bear food habits, although local factors are important to understanding why many of these changes differed between the two study areas. For instance, the increasing consumption of late Vaccinium fruits in Narcea (Table 4) could be explained by the lower herbivore pressure in this area, its higher average altitudes $(7 \%$ versus $3 \%$ of core areas above $1700 \mathrm{~m}$ ) making available an additional bilberry species (Vaccinium uliginosum) and the declining trend in acorn availability that may have forced bears to extend the period during which they feed on Vaccinium fruits. In Somiedo, the higher density of competitors, and the positive relationship between herbivore pressure and altitude (Fernández-Calvo \& Obeso 2004) played the major role in explaining the negative trend in late Vaccinium fruits in this area. Ungulate densities in Somiedo (wild plus domestic $=4011 \mathrm{~kg} \mathrm{~km}^{-2}$ ) doubled those recorded in the eastern brown bear subpopulation (1892 kg km${ }^{-2}$; Purroy et al. 1988; Clevenger et al. 1992), and they were much higher than those reported in a primeval forest in Poland $\left(612 \mathrm{~kg}\right.$ wild ungulates $\mathrm{km}^{-2}$; Jedrzejewski et al. 2002). Ungulate density in Somiedo was also higher than that reported by Ripple and Beschta (2004) in the area with the highest ungulate density of Yellowstone (around $1500 \mathrm{~kg} \mathrm{~km}^{-2}$ using the qualitative 'Ungulate biomass index' of Fuller 1989, and considering the mean biomass of a European red deer equivalent to that of the similar-sized American caribou). The Yellowstone area supports some of the highest native ungulate densities in North America (Mattson 1997), and it could be used as a reference area for ungulate densities recorded in Somiedo. Densities of free-ranging domestic ungulates in Somiedo are one order of magnitude above those of wild ungulates (Fig. 2), and should be considered as important competitors for brown bears.

The high densities of competitors in Somiedo may explain why decreasing food items in this area are mainly upland grazed items (graminoids and Vaccinium), while bears increasingly consumed Prunus and Rubus fruits, which are less influenced by herbivore pressure (at least the former), and occur in valley bottoms. Other local factors such as mountain tourism and other outdoor recreational activities, which have increased in the Somiedo area, might also explain this change from upland to lowland foods (Naves et al. 2001). These activities negatively impact bears (White et al. 1999; Naves et al. 2001) and may increase use of more sheltered forest patches and river basins with Prunus and Rubus fruits and avoid open areas (Naves et al. 2001) where graminoids and Vaccinium shrubs occur.

Brown bear food habits depend on food availability and trade-offs imposed by nutritional and energetic constraints (Welch et al. 1997; Rode \& Robbins 2000). The decrease in the consumption of acorns in Narcea may have diminished the protein intake from plant material (Grodzinski \& SawickaKapusta 1970; Jordano 1995). The food items showing increasing trends in Somiedo generally had lower protein contents than decreasing food items (Craighead et al. 1995; Jordano 1995; Welch et al. 1997). High carbohydrate and low protein content characterize this kind of fruit-based diet (Welch et al. 1997; Rode \& Robbins 2000), which may pose difficulties for Cantabrian brown bears during hyperphagia.

Our results highlight that the effects of global warming on ecosystems can be complex, with interactions between global and local factors that finally determine not only the availability of resources, but also the use of space, time and the nutritional balance of species. Because of this complexity, we should be prudent about oversimplified assumptions concerning the effects of global warming on ecological processes and biodiversity.

\section{Conservation implications}

Although it is not possible to prevent changes in food availability driven by climate warming, we must adopt management actions that minimize their predicted effects on the population. We documented how bears have come to consume less Vaccinium fruits at low altitudes as a potential response of this species to recent climate warming. Since this food item has proved to be highly attractive to brown bears wherever it occurs (LeFranc et al. 1987), heath-like formations of clumped Vaccinium shrubs at high altitudes may be critical foraging habitats for this endangered population and should receive higher conservation priorities.

Local factors such as grazing or tourism pressure need direct management, as they are the most plausible causes of some diet trends in Somiedo. Cattle herds have increased in the last two decades (Fig. 2) probably reducing food availability for bears (Anduix 2001). Thus, future habitat management within the brown bear range should include more control on cattle numbers (ideally a reduction), and/or shortening of the period of range use. Our proposals thus include the protection of critical foraging areas with restrictive access to some activities such as hunting, tourism, forestry actions and livestock grazing. Owing to recent changes in brown bear food habits, conservation efforts should also consider that bears currently seem to forage more frequently at low altitudes and on plant material poorer in protein. Because the majority of human activities occur at low altitudes, there is more probability of bear-human encounters and a higher 
proportion of bears accidentally involved in hunting activities such as driving hunts and illegal snares, mainly driven towards wild boars. At the same time, the increasing need for rich protein food items could augment the probability of attacks both on livestock and on beehives, which could change the currently positive attitude that people have towards brown bears (see also Kaczensky et al. 2004), especially if encounters trigger aggressive bear behaviour. In addition, if economic interests of the local human population are threatened, for instance, when compensation for bear damage is delayed in situ brown bear conservation may become problematic. Any small increase in mortality driven by these changes will make brown bear populations in the Cantabrian range more likely to decline, since adult and sub-adult female mortality have been identified as key factors in the population dynamics (Wiegand et al. 1998). The brown bear is considered to be a flagship and umbrella species (Meffe et al. 1994), so conservation proposals for this species are also valid for many other endangered species in the Cantabrian range, like the highly endangered Cantabrian capercaillie Tetrao urogallus cantabricus that also depends on Vaccinium fruits (Storch 1993; Rodríguez \& Obeso 2000).

\section{ACKNOWLEDGEMENTS}

Many people contributed to faeces collection and analyses, especially J. Seijas and A. Ruano. I.C. Fernández-Calvo, J. Iglesias, M. Rico and rangers from the whole Cantabrian range, especially J.M. Carral and A. Ramos in the western area, and A. González, C. Granda and S. Señas in the central area. We thank F. Braña, J.C. del Campo, C. Lastra, G. Palomero, P. Garzón, and F. Palacios for access to original data on brown bear diet. We are indebted to J. Seoane for advice on GAM and to $P$. Jordano for information on fruiting and plant ecology. This paper is a contribution to the projects Fremd F+E 0302 UFZ-CSIC and Plan Nacional de I+D+I BOS2001-2391CO2-02 (Ministerio de Educación y Ciencia, Spain) and we acknowledge Thorsten Wiegand as primary researcher of the first project.

\section{References}

Anduix, X. (2001) Trophic relationships among wild and domestic ungulates and the brown bear in the Somiedo Natural Park (Asturias, Spain). Master's thesis, UFR Sciences et Techniques, Université François Rabelais, Tours, France (in Spanish).

Beerling, D.J. (1999) Long-term responses of boreal vegetation to global change: an experimental and modelling investigation. Global Change Biology 5: 55-74.

Clevenger, A.P., Purroy, F.J. \& Pelton, M.R. (1992) Food habits of brown bears (Ursus arctos) in the Cantabrian Mountains, Spain. Journal of Mammalogy 73: 415-421.

Consejería de Medio Ambiente del Principado deAsturies (2000) Hunting statistics and hunting planning 2000/2001. Unedited report, Government of Asturies, Spain (in Spanish).

Craighead, J.J. \& Mitchell, J.A. (1982) The grizzly bear. In: Wild Mammals of North America, ed. G.A. Feldhamer, B.C. Thompson
\& J.A. Chapman, pp. 515-554. Maryland, USA: John Hopkins University Press.

Craighead, J.J., Sumner, J.S. \& Mitchell, J.A. (1995) Food habits and feeding behavior of the grizzly bear population. In: The Grizzly Bears of Yellowstone. Their Ecology in the Yellowstone Ecosystem, 1959-1992, ed. Craighead Wildlife-Wildlands Institute, pp. 233276. Washington, DC, USA: Island Press.

Eriksson, O. \& Ehrlén, J. (1991) Phenological variation in fruit characteristics in vertebrate-dispersed plants. Oecologia 86: 463470 .

Fernández-Calvo, I.C. \& Obeso, J.R. (2004) Growth, nutrient content, fruit production and herbivory in bilberry Vaccinium myrtillus L. along an altitudinal gradient. Forestry 77: 213223.

Fernández-Gil, A., Naves, J. \& Delibes, M. (2006) Courtship of brown bears Ursus arctos in northern Spain: phenology, weather, habitat and durable mating areas. Wildlife Biology 12: 367-373.

Fuller, T.K. (1989) Population dynamics of wolves in North central Minnesota. Wildlife Monographs 105: 1-41.

García, D., Quevedo, M., Obeso, J.R. \& Abajo, A. (2005) Fragmentation patterns and protection of montane forest in the Cantabrian range (NW Spain). Forest Ecology and Management 208: 29-43.

Grodzinski, W. \& Sawicka-Kapusta, K. (1970) Energy values of tree-seeds eaten by small mammals. Oikos 21: 52-58.

Hampe, A. (2005) Fecundity limits in Frangula alnus (Rhamnaceae) relict populations at the species' southern range margin. Oecologia 143: 377-386.

Hampe, A. \& Petit, R.J. (2005) Conserving biodiversity under climate change: the rear edge matters. Ecology Letters 8: 461-467.

Hastie, T.J. \& Tibshirani, R.J. (1990) Generalized Additive Models. London, UK: Chapman \& Hall.

Herrera, C.M., Jordano, P., Guitián, J. \& Traveset, A. (1998) Annual variability in seed production by woody plants and the masting concept: reassessment of principles and relationship to pollination and seed dispersal. American Naturalist 152: 576594.

Hurrel, J.W. \& van Loon, H. (1997) Decadal variations in climate associated with the North Atlantic Oscillation. Climate Change 36: 1085-1093.

IPCC (2001) Climate Change 2001: the Scientific Basis. Cambridge, UK: Intergovernmental Panel on Climate Change.

Jedrzejewski, W., Schmidt, K., Theuerkauf, J., Jedrzejewska, B., Selva, N., Zub, K. \& Szymura, L. (2002) Kill rates and predation by wolves on ungulate populations in Bialowieza primeval forest (Poland). Ecology 83: 1341-1356.

Jordano, P. (1995) Angiosperm fleshy fruits and seed dispersers: a comparative analysis of adaptation and constraints in plant-animal interactions. American Naturalist 145: 163-191.

Jump, A.S. \& Penuelas, J. (2005) Running to stand still: adaptation and the response of plants to rapid climate change. Ecology Letters 8: 1010-1020.

Kaczensky, P., Blazic, M. \& Gossow, H. (2004) Public attitudes towards brown bears (Ursus arctos) in Slovenia. Biological Conservation 118: 661-674.

Koenig, W.D. \& Knops, M.H. (2000) Patterns of annual seed production by Northern Hemisphere trees: a global perspective. American Naturalist 155: 59-69.

LeFranc, M.N., Moss, M.B., Patnode, K.A. \& Sugg, W.C. (1987) Grizzly Bear Compendium. Washington, DC, USA: Interagency Grizzly Bear Commitee. 
Llaneza, L. (1996) Prey selection and food habits of Iberian wolfs (Canis lupus) in Somiedo Natural park. Master's thesis, Universidad de Oviedo, Oviedo, Spain (in Spanish).

Mattson, D.J. (1997) Use of ungulates by Yellowstone grizzly bears Ursus arctos. Biological Conservation 81: 161-177.

Mattson, D.J., Blanchard, B.M. \& Knight, R.R. (1991) Food habits of Yellowstone grizzly bears, 1977-1987. Canadian fournal of Zoology 69: 1619-1629.

McCullagh, P. \& Nelder, J.A. (1983) Generalised Linear Modelling. London, UK: Chapman and Hall.

Meffe, G.K., Carroll, C.R. \& contributors (1994) Principles of Conservation Biology. Sunderland, MA, USA: Sinauer Associates.

Naves, J., Fernández, A. \& Delibes, M. (2001) Effects of recreation activities on a brown bear family group in Spain. Ursus 12: 135140 .

Naves, J., Fernández-Gil, A., Rodriguez, C. \& Delibes, M. (2006) Brown bear food habits at the border of its range: a long-term study. Fournal of Mammalogy 87: 899-908.

Naves, J., Wiegand, T., Revilla, E. \& Delibes, M. (2003) Endangered species constrained by natural and human factors: the case of Brown Bears in Northern Spain. Conservation Biology 17: 12761289.

Obeso, J.R. \& Bañuelos, M.J. (2003) The Capercaillie (Tetrao urogallus cantabricus) in the Cantabrian Mountains. Madrid, Spain: Ministerio de Medio Ambiente (in Spanish).

Ögren, E. (1996) Premature dehardening in Vaccinium myrtillus during a mild winter: a cause for winter dieback? Functional Ecology 10: 724-732.

Osborn, T.J. \& Briffa, K.R. (2006) The spatial extent of 20th-century warmth in the context of the past 1200 years. Science 311: 841-844.

Ottersen, G., Planque, B., Belgrano, A., Post, E., Reid, P.C. \& Stenseth, N.C. (2001) Ecological effects of the North Atlantic Oscillation. Oecologia 128: 1-14.

Parmesan, C., Ryrholm, N., Stefanescu, C., Hill, J.K., Thomas, C.D., Descimon, H., Huntley, B., Kaila, L., Kullberg, J., Tammaru, T., Tennent, W.J., Tomas, J.A. \& Warren, M. (1999) Poleward shifts in geographical ranges of butterfly species with regional warming. Nature 399: 579-583.

Peñuelas, J. \& Boada, M. (2003) A global change-induced biome shift in the Montseny mountains (NE Spain). Global Change Biology 9 : 131-140.

Peñuelas, J. \& Filella, I. (2001) Responses to a warming world. Science 294: 793-795.

Peñuelas, J., Filella, I. \& Comas, P. (2002) Changed plant and animal life cycles from 1952 to 2000 in the Mediterranean region. Global Change Biology 8: 531-544.

Pimm, S.I., Russel, G.J., Gittelman, J.L. \& Brooks, T.M. (1995) The future of biodiversity. Science 269: 347.

Polunin, O. \& Walters, M. (1985) A Guide to the Vegetation of Britain and Europe. Oxford, UK: Oxford University Press.

Purroy, F.J., Clevenger, A.P., Costa, L. \& Saenz de Buruaga, M. (1988) Demography of big mammals (wild boar, roe deer, red deer, wolf and bear) in the National Hunting Reserve of Riaño: analysis of predation and influence on livestock. Biología Ambiental 1: 375-387 (in Spanish).

Ripple, W.J. \& Beschta, R.L. (2004) Wolves and the ecology of fear: can predation risk structure ecosystems? Bioscience 54: 755766.

Rode, K.D. \& Robbins, C.T. (2000) Why bears consume mixed diets during fruit abundance. Canadian Fournal of Zoology 78: 16401645 .

Rodriguez, C. \& Bustamante, J. (2003) The effect of weather on lesser kestrel breeding success: can climate change explain historical population declines? Fournal of Animal Ecology 72: 793-810.

Rodríguez, E. \& Obeso, J.R. (2000) Diet of the Cantabrian capercaillie: geographic variation and energetic content. Ardeola 47: 77-83.

Servheen, C., Herrero, S. \& Peyton, B. (1999) Bears: Status Survey and Conservation Action Plan. Gland, Switzerland and Cambridge, UK: International Union for Conservation of Nature and Nature Resources.

Storch, I. (1993) Habitat selection by capercaillie in summer and autumn: is bilberry important? Oecologia 95(2): 257-265.

Sukopp, H. \& Wurzel, A. (2003) The effect of climate change on the vegetation of central european cities. Urban habitats 1 : $66-86$

Taulavuori, K., Laine, K., Taulavuori, E., Pakonen, T. \& Saari, E. (1998) Accelerated dehardening in bilberry (Vaccinium myrtillus L.) induced by a small elevation in air temperature. Environmental Pollution 98: 91-95.

Thomas, C.D., Cameron, G.N., Green, R.E., Bakkenes, M., Beaumont, L.J., Collingham, Y.C., Erasmus, B.F.N., de Siqueira, M.F., Grainger, A., Hannah, L., Hughes, L., Huntley, B., van Jaarsveld, A.S., Midgley, G.F., Miles, L., Ortega-Huerta, M.A., Peterson, A.T., Phillips, O.L. \& Williams, S.E. (2004) Extinction risk from climate change. Nature 427: 145-148.

Tolvanen, A. \& Taulavuori, K. (1998) Timing of deacclimation affects the ability to recover from simulated winter herbivory. Plant Ecology 135: 9-12.

Vicente-Serrano, S.M. \& Heredia-Laclaustra, A. (2004) NAO influence on NDVI trends in the Iberian Peninsula (1982-2000). International Fournal of Remote Sensing 25: 2871-2879.

Visser, M.E., Van Noordwijk, A.J., Tinbergen, J.M. \& Lessells, C.M. (1998) Warmer springs lead to mistimed reproduction in great tits (Parus major). Proceedings of the Royal Society of London B 265: $1867-1870$.

Welch, C.A., Keay, J., Kendall, K.C. \& Robbins, C.T. (1997) Constrains on frugivory by bears. Ecology 78: 1105-1119.

White Jr, D., Kendall, K.C. \& Picton, H.D. (1999) Potential energetic effects of mountain climbers on foraging grizzly bears. Wildlife Society Bulletin 27: 146-151.

Wiegand, T., Naves, J., Stephan, T. \& Fernández, A. (1998) Assesing the risk of extinction for the brown bear (Ursus arctos) in the Cordillera Cantabrica, Spain. Ecological Monographs 68: 539570 . 